\title{
Analisis Reliabilitas dengan Distribusi Weibull 2 Peubah Pada Tingkat Kelangsungan Hidup Penderita Penyakit Kanker Paru-Paru
}

\begin{abstract}
Anna Islamiyati*
Abstrak

Analisis Reliabilitas digunakan untuk melihat tingkat keandalan suatu produk atau sistem dalam berbagai bidang kehidupan. Secara statistik, salah satu metode yang dapat digunakan dalam analisis reliabilitas adalah distribusi Weibull, yang ditunjukkan melalui 2 peubah, $\mathbf{x}$ dan y. Ilustrasi menggunakan data pada tingkat kelangsungan hidup penderita penyakit kanker paru-paru berdasarkan lama perawatan pasien di rumah sakit. Disini tidak dijelaskan metodologi penelitian karena data yang diangkat hanyalah data sekunder yang telah dilakukan pada kegiatan hibah penelitian.
\end{abstract}

Kata Kunci : reliabilitas, tingkat kelangsungan hidup dan distribusi weibull.

\section{Pendahuluan}

Dewasa ini, teori keandalan semakin dibutuhkan baik dalam dunia industri, pendidikan, kedokteran dan berbagai bidang lainnya. Kualitas produk yang andal atau kualitas sistem pelayanan yang baik menjadi kunci utama dalam kesuksesan bisnis atau program. Inovasi-inovasi baru perlu mengetahui tingkat keandalan setiap komponen yang digunakan supaya memiliki mutu yang lebih bersaing di pasaran.

Kajian tentang keandalan biasanya dianalisis dalam analisis reliabilitas dan salah satu distribusi yang dapat digunakan adalah Distribusi Weibull.

Dalam tulisan ini, akan ditunjukkan pendeteksian awal data dengan menggunakan distribusi weibull dengan 2 peubah sebelum masuk dalam analisis reliabilitas. Dan sebagai ilustrasi akan digunakan data lama perawatan pasien pengidap kanker paru-paru dalam menganalisis tingkat kelangsungan hidup pasien melalui analisis reliabilitas. Melalui tulisan ini, diharapkan penggunaan analisis reliabilitas dengan distribusi data dapat lebih banyak dimanfaatkan oleh pengguna statistik, sehingga tidak hanya terbatas pada analisis parametrik dan non parametrik saja seperti yang digunakan selama ini.

\section{Teori Pendukung}

\subsection{Distribusi Weibull dalam Teori Reliabilitas}

Peubah acak kontinu T yang berdistribusi Weibull untuk parameter $\alpha$ dan $\beta$, memiliki fungsi kepadatan sebagai berikut :

$$
f(t)=\alpha \beta t^{\beta-1} e^{-\alpha t^{\beta}} \quad ; \quad \mathrm{t}>0, \alpha>0 \text { dan } \beta>0
$$

\footnotetext{
* Staf Pengajar pada Jurusan Matematika F.MIPA Universitas Hasanuddin Makassar
} 


\section{Anna Islamiyati}

Penggunaan Distribusi Weibull dalam teori keandalan produk menjelaskan tentang tingkat keandalan dan tingkat kegagalan dari produk tersebut. Tingkat keandalan disimbolkan $\mathrm{R}(\mathrm{t})$ yang dapat ditulis sebagai berikut :

$$
R(t)=P(T>t)=\int_{t}^{\infty} f(t) d t=1-F(t)
$$

jika $\mathrm{F}(\mathrm{t})$ menyatakan distribusi kumulatif $\mathrm{T}$.

Peluang bersyarat bahwa sebuah produk/sistem akan gagal dalam selang waktu $\mathrm{T}=\mathrm{t}$ sampai $\mathrm{T}=\mathrm{t}+\Delta \mathrm{t}$, bila diketahui dapat bertahan sampai batas waktu $\mathrm{t}$ yang telah diperkirakan/ditentukan, diberikan oleh :

$$
\frac{F(t+\Delta t)-F(t)}{R(t)}
$$

Bila nisbah dibagi dengan $\Delta \mathrm{t}$ dan diambil limitnya dengan membuat $\Delta \mathrm{t} \rightarrow 0$ maka diperoleh tingkat kegagalan yang disimbol Z(t) sebagai berikut:

$$
Z(t)=\alpha \beta t^{\beta-1}
$$

Hubungan $\mathrm{R}(\mathrm{t})$ dan $\mathrm{Z}(\mathrm{t})$ ditunjukkan pada persamaan berikut :

$$
\begin{aligned}
Z(t) & =\lim _{\Delta t \rightarrow 0} \frac{F(t+\Delta t)-F(t)}{\Delta t} \frac{1}{R(t)} \\
& =\frac{F^{\prime}(t)}{R(t)}=\frac{f(t)}{R(t)}=\frac{f(t)}{1-F(t)}
\end{aligned}
$$

karena $\mathrm{R}(\mathrm{t})=1-\mathrm{F}(\mathrm{t})$ dan $\mathrm{R}^{\prime}(\mathrm{t})=\mathrm{F}^{\prime}(\mathrm{t})$, maka :

$$
\begin{aligned}
Z(t)=\frac{-R^{\prime}(t)}{R(t)} & =\frac{-d[\ln R(t)]}{d t} \\
\ln R(t) & =-\int Z(t) d t \\
R(t) & =e^{-\int Z(t) d t}+c=e^{-\alpha t^{\beta}}+c
\end{aligned}
$$

Sehingga dari pers (4) dan (6) maka :

$$
f(t)=Z(t) R(t)
$$

$f(t)$

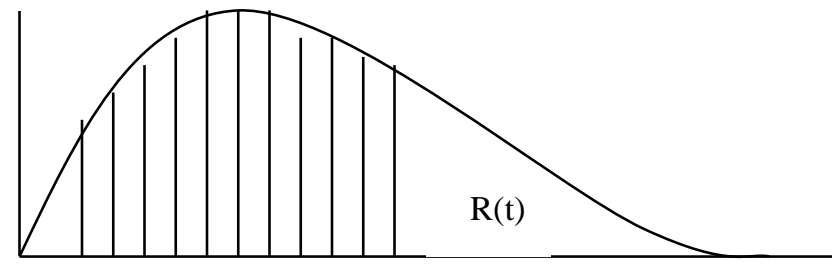

0

$\mathrm{t}$

Gambar 1 . suve.. Jusi Waktu Kegagalan 


\section{Anna Islamiyati}

\subsection{Tingkat Kelangsungan Hidup}

Analisis Tingkat Kelangsungan Hidup biasa disebut Analisis Survival adalah analisis data yang menggambarkan waktu terjadinya sebuah kejadian tertentu ke titik akhir kejadian itu ("Time to Event" data). Dalam dunia kedokteran, titik akhir kejadian dapat digambarkan sebagai kejadian pasien yang meninggal, sembuh dari penyakitnya, atau munculnya kembali gejala suatu penyakit. Tujuan Analisis Survival ini untuk mengidentifikasi variabel ramalan yang penting untuk waktu kelangsungan hidup pasien. Tingkat kelangsungan hidup ini merupakan salah satu ukuran yang dapat ditunjukkan melalui analisis reliabilitas, termasuk dalam dunia kedokteran

Dalam analisis Survival ini melibatkan peubah yang berdistribusi weibull yang menggambarkan peluang kegagalan dan keandalan pasien dalam bertahan hidup dalam proses penyembuhannya.

Ukuran reliabilitas ada yang dikategorikan repairable yaitu tingkat kegagalan lebih dari satu kali artinya ada kemungkinan suatu produk untuk berfungsi kembali kemudian rusak kembali pada waktu tertentu dan ada pula yang masuk dalam kategori non-repairable yaitu tingkat kegagalan satu kali atau kemampuan produk hanya satu kali.

Produk yang repairable akan menggunakan MTBF (Mean Time Between Failure) dan Availability. MTBF adalah rata-rata waktu sistem akan beroperasi sampai terjadi kegagalan berikutnya. Availability adalah proporsi waktu suatu sistem dapat dioperasikan.

MTTR (Mean Time to Repair) adalah waktu rata-rata untuk memperbaiki, di mana suatu produk atau sistem mulai rusak sampai selesai diperbaiki.

$$
\begin{aligned}
& M T T R=\frac{\text { Total Waktu Perbaikan }}{\text { Total Tingkat Kegagalan }} \\
& M T B F=\frac{1}{\text { Tingkat Kegagalan }} \\
& \text { Availability }=\frac{M T B F}{M T B F+M T T R}
\end{aligned}
$$

Sedangkan produk non-repairable menggunakan MTTF (Mean Time to Failure) dan Hazard Rate. MTTF adalah rata-rata waktu suatu sistem akan beroperasi sampai terjadi kegagalan pertama kali. Hazard Rate adalah tingkat kegagalan suatu komponen hingga waktu tertentu atau sebagai fungsi sampai berapa lama komponen dapat digunakan.

$$
\begin{aligned}
& \text { MTTF }=\frac{1}{\text { Hazard Rate }} \\
& \text { Hazard Rate }=\frac{\text { Probabilitas Komponen Gagal Saat } t}{\text { Re liabilitas Komponen Hingga Waktut }}
\end{aligned}
$$

\section{Pendeteksian Distribusi Data dengan Weibull}

Pendeteksian distribusi data sangat penting sebagai langkah awal dalam analisis reliabilitas. Pendeteksian ini berguna untuk melihat ketepatan distribusi dengan data hasil penelitian melalui metode maksimum likelihood. Pendeteksian ini akan ditunjukkan melalui plot probabilitas dan nilai Anderson Darling dari Distribusi Weibull 2 peubah seperti yang ditunjukkan pada gambar berikut. 


\section{Anna Islamiyati}
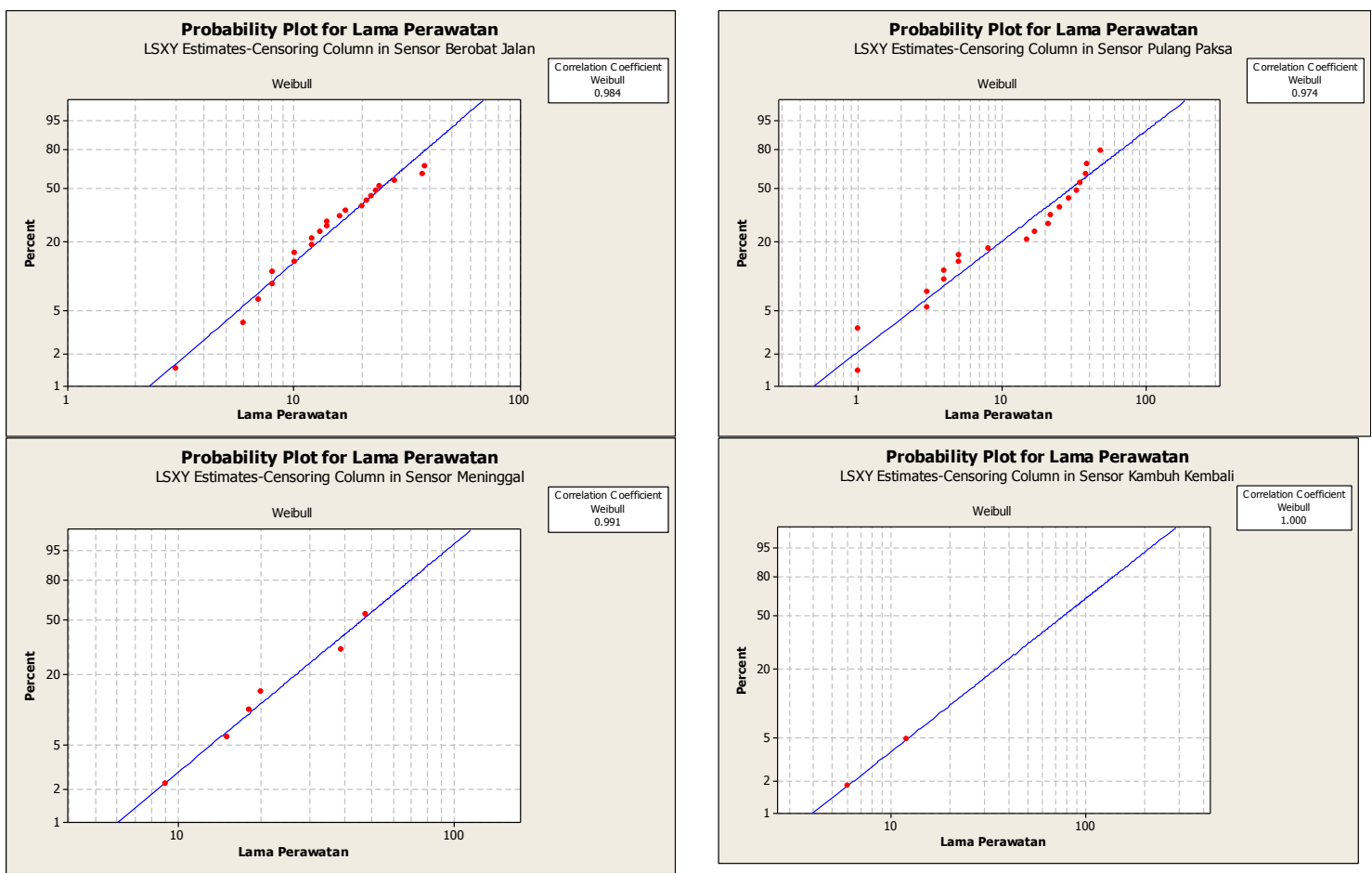

Gambar 2 : Plot Probabilitas Untuk Lama Perawatan Pasien Penyakit Kanker Paru-Paru Berdasarkan Status Kelangsungan Hidup Pasien

Hasil plot data seperti pada Gambar 2 di atas menunjukkan plot probabilitas data sudah mendekati garis lurus dengan nilai Anderson Darling dari distribusi weibull untuk pasien yang berobat jalan sebesar 59,258, pasien yang pulang paksa sebesar 20,752, pasien yang meninggal sebesar 31,674 dan pasien yang kambuh kembali sebesar 48,098 dengan nilai koefisien korelasi rata-rata di atas 0,9 . Sehingga dapat disimpulkan bahwa analisis reliabilitas dengan distribusi weibull dapat digunakan dalam memprediksi kondisi pasien penyakit kanker paru-paru selama perawatan pada Rumah Sakit Wahidin Sudirohusodo pada 50 pasien.

Melalui distribusi weibull, rata-rata lama perawatan pasien yang berobat jalan adalah 26,057 hari, dengan selang kepercayaan 95\% berkisar antara $\quad 21,173-32,067$ hari, artinya bila diputuskan bahwa data pasien mengikuti distribusi weibull, maka $95 \%$ pasien yang menjalani perawatan kemudian berobat jalan akan berada antara 21,173 - 32,067 hari perawatan. Untuk pasien yang pulang paksa rata-rata perawatan sekitar 41,904 hari dengan kisaran 23,181 - 75,750 hari yang dijalani oleh sekitar $95 \%$ pasien. Rata-rata perawatan pasien yang meninggal sekitar 48,791 hari dengan 95\% pasien akan berada pada kisaran 30,109 - 79,067 hari. Sedangkan untuk pasien yang penyakitnya kambuh kembali memiliki rata-rata perawatan yang paling tinggi yaitu sekitar 89,742 hari dengan 95\% pasien akan berada pada kisaran 30,702 - 262,311 hari. Lama tidaknya perawatan pasien di rumah sakit juga dipengaruhi oleh faktor kondisi kesehatan pasien maupun dari faktor lain misalnya faktor keuangan, pelayanan rumah sakit, dan lain-lainnya yang tidak diteliti dalam penelitian ini.

Taksiran parameter untuk masing-masing status pasien ditunjukkan pada Tabel 2 berikut. 


\section{Anna Islamiyati}

Tabel 2. Fungsi Distribusi Weibull Berdasarkan Status Kelangsungan Hidup Pasien untuk Parameter $\alpha$ dan $\beta$

\begin{tabular}{|l|c|}
\hline \multicolumn{1}{|c|}{ Status } & Fungsi Distribusi Weibull \\
& $f(t)=\alpha \beta t^{\beta-1} e^{-\alpha t^{\beta}}$ \\
\hline Berobat Jalan & $f(t)=53,05 t^{0,81} e^{-29,31 t^{1,81}}$ \\
Pulang Paksa & $f(t)=43,70 t^{0,03} e^{-42,43 t^{1,03}}$ \\
Meninggal & $f(t)=114,57 t^{28,31} e^{-55,08 t^{2,08}}$ \\
Kambuh Lagi & $f(t)=141,23 t^{0,43} e^{-98,76 t^{1,43}}$ \\
\hline
\end{tabular}

\section{Analisis Reliabilitas dalam Tingkat Kelangsungan Hidup Penderita Penyakit Kanker Paru-Paru}

Untuk analisis reliabilitas, akan ditunjukkan tingkat keandalan dan tingkat kegagalan dari keseluruhan pasien yang kemudian akan digunakan untuk menjelaskan tingkat kelangsungan hidup pasien dengan memperhatikan status kelangsungan hidup mereka sesuai data hasil penelitian, yaitu pasien yang berobat jalan, pulang paksa, meninggal dan kambuh kembali. Pasien yang berobat jalan dan pulang paksa dikategorikan sebagai pasien yang mampu bertahan hidup sampai akhir perawatan sedangkan pasien yang meninggal dan kambuh kembali dikategorikan sebagai pasien yang gagal bertahan hidup dan gagal untuk sembuh dari penyakit yang dideritanya.

Kondisi pasien dengan beberapa kemungkinan tersebut menunjukkan bahwa tingkat kegagalan pada pasien bermacam-macam sehingga ukuran reliabilitas untuk kondisi pasien ada yang dikategorikan repairable yaitu tingkat kegagalan lebih dari satu kali artinya ada kemungkinan pasien untuk sembuh kemudian kambuh atau baru meninggal pada waktu tertentu dan ada pula yang masuk dalam kategori non-repairable yaitu tingkat kegagalan satu kali atau hidupnya hanya satu kali.

Dalam penelitian ini, status kelangsungan hidup penderita penyakit kanker paru-paru dibagi dalam 5 kategori yaitu pasien yang sembuh, pulang paksa, berobat jalan, meninggal dan kambuh kembali penyakitnya. Masing-masing kategori menunjukkan status kelangsungan hidup pasien yang berbeda-beda. Hal yang paling menonjol adalah pasien yang sembuh dan meninggal, karena dari dua kondisi pasien ini, dapat memberikan keterangan tentang kemampuan pasien untuk bertahan hidup, apakah akan sembuh dari penyakit kanker paru-paru atau sebaliknya meninggal karena serangan penyakit tersebut. Sedangkan ketiga kondisi lainnya yaitu pulang paksa, berobat jalan dan kambuh lagi memiliki dua kemungkinan yaitu sembuh atau akan meninggal.

Tetapi karena pasien yang sembuh tidak didapatkan dalam penelitian maka hanya 4 status pasien yang akan dibahas dan semuanya dikategorikan dalam pasien non repairable karena data yang didapatkan hanya menunjukkan lama perawatan pasien sampai pada keadaan sensor atau status pasien yaitu berobat jalan, pulang paksa, meninggal atau kambuh kembali.

Tingkat kegagalan pasien adalah kegagalan pasien untuk dapat bertahan hidup (meninggal) atau penyakitnya kambuh kembali selama masa perawatan di rumah sakit dari penyakit kanker paru-paru yang dideritanya. Untuk semua pasien nilai parameter yang diperoleh adalah $\alpha=53,12$ dan $\beta=1,76$ sehingga bentuk persamaannya ditunjukkan seperti berikut : 


\section{Anna Islamiyati}

$$
\begin{aligned}
& f(t)=93,49 t^{0,76} e^{-53,12 t^{2,76}} \\
& Z(t)=(93,49) t^{0,76} \text { dan } \quad R(t)=e^{-53,12 t^{2,76}}
\end{aligned}
$$

Rata-rata lama perawatan pasien di rumah sakit kemudian mengalami kematian atau pun kambuh kembali penyakitnya sekitar 47,299 hari yang berada pada interval 29,398 - 76,104 hari perawatan. Hasil analisis menunjukkan bahwa sekitar $30 \%$ pasien akan meninggal setelah dirawat selama 29,56 hari atau sekitar 1 bulan di rumah sakit. Pasien yang bisa bertahan hidup melewati 1 bulan sebesar $69,35 \%$ dan $50 \%$ pasien hanya mampu bertahan selama 1,5 bulan. Keadaan ini tentunya harus menjadi bahan evaluasi bagi rumah sakit maupun dari pasien karena faktor utama penyebab kematian pasien karena keterlambatan dari pasien sendiri dalam melakukan pengobatan di rumah sakit sehingga perawatan sejak dini tidak dapat dilakukan lagi oleh pihak rumah sakit. Di sisi lain keterlambatan pasien bukan karena faktor ketidaktahuan tetapi pada umumnya disebabkan oleh faktor ekonomi, sehingga tim manajemen rumah sakit perlu untuk mengkaji lebih lanjut tentang permasalahan tersebut.

Nilai taksiran reliabilitas pada lama perawatan pasien, dapat dilihat pada grafik berikut.

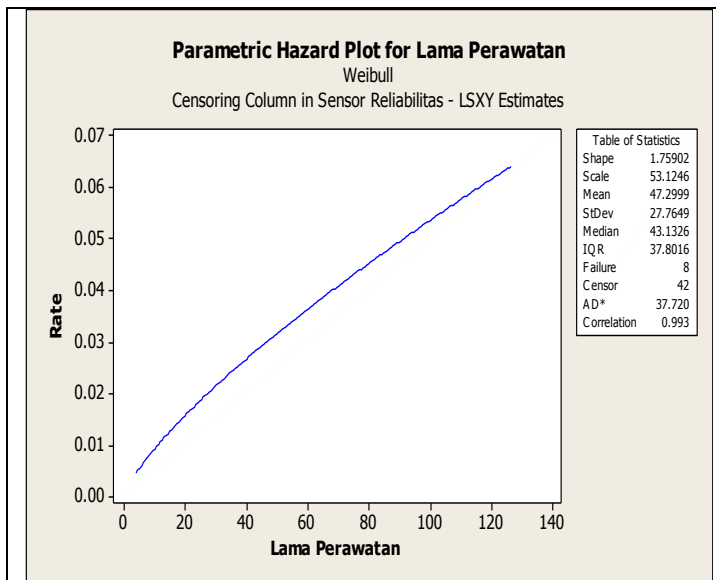

(a)

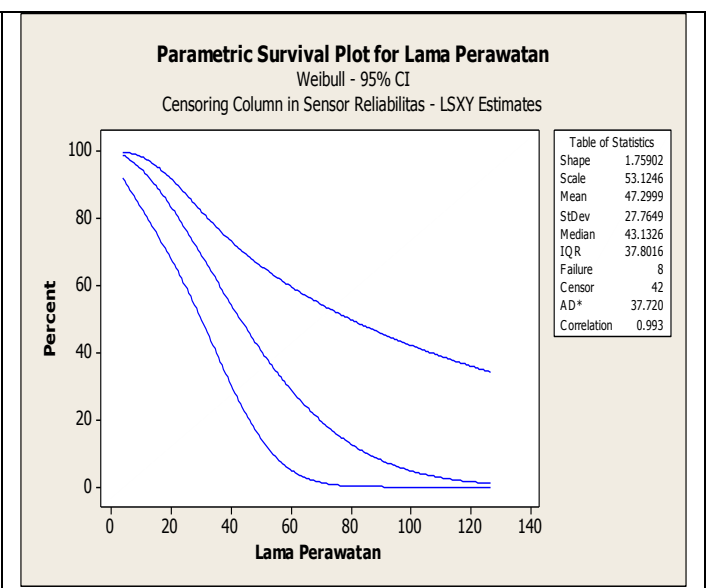

(b)

Gambar 3 : Plot Hazard Rate (a) dan Plot Survival (b) Lama Perawatan Pasien

Gambar di atas menunjukkan reliabilitas pasien selama dirawat semakin lama semakin mengalami penurunan sedangkan peluang kegagalan pasien selama dalam perawatan mengalami peningkatan. Terlihat bahwa setelah pasien dirawat selama 30 hari reliabilitasnya menurun sebesar $68,16 \%$ dan terus mengalami penurunan seiring dengan bertambahnya lama perawatan di rumah sakit. Sedangkan total pasien yang gagal sampai 30 hari sekitar 31,84\%. Hasil ini menunjukkan bahwa semakin lama pasien dirawat di rumah sakit maka tingkat reliabilitasnya semakin rendah, sebaliknya tingkat kegagalannya semakin tinggi.

Selengkapnya, peluang tingkat kegagalan dan tingkat keandalan pasien selama masa perawatan ditunjukkan pada Tabel 3.: 


\section{Anna Islamiyati}

Tabel 3. Tingkat kegagalan dan tingkat keandalan pasien selama masa perawatan

\begin{tabular}{|c|c|c|}
\hline $\begin{array}{c}\text { Lama Perawatan } \\
(\text { Hari })\end{array}$ & Tingkat Kegagalan $(\mathbf{Z}(\mathbf{t}))$ & $\begin{array}{c}\text { Tingkat Keandalan } \\
(\mathbf{R}(\mathbf{t}))\end{array}$ \\
\hline 6 & 0,006 & 0,979 \\
12,2 & 0,011 & 0,928 \\
18,4 & 0,015 & 0,857 \\
24,6 & 0,018 & 0,772 \\
30,8 & 0,022 & 0,682 \\
37 & 0,025 & 0,589 \\
43,2 & 0,028 & 0,499 \\
49,4 & 0,031 & 0,415 \\
55,6 & 0,034 & 0,338 \\
61,8 & 0,037 & 0,271 \\
68 & 0,040 & 0,214 \\
74,2 & 0,043 & 0,165 \\
80,4 & 0,045 & 0,126 \\
86,6 & 0,048 & 0,094 \\
92,8 & 0,051 & 0,069 \\
99 & 0,053 & 0,050 \\
105,2 & 0,056 & 0,036 \\
111,4 & 0,058 & 0,025 \\
117,6 & 0,061 & 0,017 \\
123,8 & 0,063 & 0,019 \\
\hline
\end{tabular}

\section{Kesimpulan}

- Untuk mengetahui keandalan suatu produk/sistem, analisis pemecahan yang dapat digunakan adalah analisis reliabilitas dengan distrbusi weibull.

- Analisis reliabilitas dapat digunakan dalam menjelaskan tingkat kelangsungan hidup pasien penderita kanker paru-paru.

- Dalam analisis reliabilitas dengan distribusi weibull menunjukkan bahwa semakin lama suatu produk/pasien maka tingkat keandalannya akan mengalami penurunan tetapi sebaliknya tingkat kegagalan semakin tinggi.

\section{Daftar Pustaka}

[1] William Feller, 1982, "Probability Theory and Its Apllications", Third Printing. John Wiley \& Sons. The United States of America.

[2] Ibrahim J.G., Chen, MH and Shina, D., 2001, "Bayesian Survival Analysis" Springer Verlag, New York.

[3] Lee E.T., 1992, "Statistical Methods for Survival Data Analysis”, John Wiley and Sons Inc., Canada. 